\title{
Islamic Corporate Social Responsibility (ICSR) disclosure and Islamic Banks (IBs) performance: The application of stakeholder theory from Islamic perspective
}

\author{
Ichsan Setiyo Budi \\ Faculty of Economics and Business, Universitas Pembangunan Nasional "Veteran" Yogyakarta, Yogyakarta, Indonesia \\ ${ }^{*}$ Corresponding author email: ichsan.setiyobudi@upnyk.ac.id
}

\section{A R T I C L E I N F O}

Article history:

Available online

Keywords:

ROA, ROE, ICSR, AAOIFI, ISlamic

Banking

DOI:

https://doi.org/10.20885/jaai.vol25.i ss1.art8

\section{A B S T R A C T}

This study aims to examine the effect of ICSR disclosure on the performance of IBs in Indonesia. Disclosures are prepared based on AAOIFI standards and previous researches then formed a disclosure index, while the performance of IBs is compiled from financial performances: ROA, ROE, and productivity performances which are formed into variables are formed by factor analysis. The samples of this research are 12 IBs from 2008 until 2019. Several IBs that had not yet been established in 2008 had been observed since the establishment of the banks until 2019, from this, it is obtained 121 observations. The test results show that all indicators of ICSR disclosure consisting of eight indicators: sharia compliance, ethical behavior, management, human resources, environment, social activities, products and services, research and development, and training have a positive effect on the performance of IBs. This provides an understanding that all of the disclosure indicators provide a good image or reputation to the public, thereby generating trust and in the longterm improving the performance of IBs.

\section{Introduction}

At present, IBs have developed into alternative financial institutions whose formations are based on Islamic ontological and epistemological sources (Platonova et al., 2018). Islam is essentially a social and environmental concern, good governance, and ethical behavior in organizations (Asutay, 2013). Therefore, ICSR practice is an enforcement of Islamic ethics because Islam as a religion implies a proactive and widespread stakeholder paradigm through corporate moral obligations towards society through substantive morality. Thus, CSR as part of a new paradigm, is an endogenous concept and practice, which is expected to become an existential part of every Islamic company, including banks and other Islamic financial institutions (Platonova et al., 2018).

The social function is a characteristic of IBs which distinguishes it from conventional banks (Law of the Republic of Indonesia Number 21 of 2008). The social function of IBs shows their contribution to the welfare of society as well as helping Muslims fulfill their religious obligations (Maali et al., 2006). Social and environmental responsibility is the responsibility of stakeholders who aim to protect their rights and interests, both horizontally and vertically or to Allah SWT, an understanding that places Allah SWT as the main stakeholder develops in stakeholder theory from an Islamic perspective and this is the main basis of this research (Iqbal \& Mirakhor, 2004).

According to Dusuki and Abdullah (2007) responsibility to stakeholders in Islam aims to align the interests of various groups, based on moral, ethical and public interest principles to avoid damage and poverty as well as the principle of obedience to Allah. Stakeholders have the right to get information on whether the company carries out social and environmental activities, so that IBs are required to disclose information that identifies themselves, including social and environmental responsibility (Bayoud et al., 2012). Haniffa (2002) explains that social responsibility reporting can be seen as a company's response to meet community expectations.

The problem with the disclosure of ICSR by Islamic institutions is that there is no standard of disclosure (Farook \& Lanis, 2005). Based on analysis in several IBs in the world, Farook and Lanis (2005) found that there is a free behavior in presenting social information in annual reports, because regulators do not regulate and require explicitly that Islamic banking provides social responsibility information. There is a need for disclosure that can cover all forms of accountability for activities in Islamic banking, in fact Accounting and Auditing Organization for Islamic Financial Institution (AAOIFI) has published an ICSR index containing a compilation of standard items of social responsibility for Islamic financial institutions. This index is then further developed by researchers in terms of ICSR disclosure items which should be a standard of disclosure in accordance with an Islamic perspective (Maali et al., 2006; Othman \& Thani, 2010). 
Researches that link ICSR disclosure with financial performance (FP) have a significant effect (Ahmed et al., 2012; Aribi \& Gao, 2011; Maali et al., 2006). Although there are many studies that attempt to investigate the relationship between corporate social responsibility and FP in conventional financial institutions, there are few studies examining this relationship in Islamic financial institutions (Mallin et al., 2014). Thus, this study aims to explore the relationship between ICSR disclosure and FP of IBs in Indonesia, assuming that there is a positive relationship between these two variables and causality that runs from ICSR disclosure to FP.

Many studies have been conducted to examine the relationship between social responsibility and FP, among others: Makni et al. (2009), Margolis and Walsh (2003), Marom (2006), Preston and O'Bannon (1997), and Ullmann (1985), are all considered important works and have been widely cited as the focus of research in this area. These studies, which have examined direction, strength and also causal relationships, have produced confirmatory and contradictory results (Platonova et al., 2018). A number of studies have assessed the relationship between social responsibility disclosure and FP in the conventional banking sector (Ahmed et al., 2012; Simpson \& Kohers, 2002; Soana, 2009). Research on IBs, for example, Arshad et al. (2012) analysed the effect of ICSR disclosure on company reputation and performance of IBs in Malaysia, and the result showed a significant positive relationship between ICSR activities and IBs performance. Other researchers, Mallin et al. (2014) where the results of their research show a significant positive relationship between ICSR disclosure and FP.

In this study, using the ICSR disclosure on IBs in Indonesia, content analysis is carried out in their annual reports. Construction of indicators and items to assess the ICSR disclosure index is based on ICSR related standards developed by AAOIFI (2010) and the previous study. As a result, eight indicators are selected: sharia compliance, ethical behavior, management, human resources, environment, social activities, products and services, research and development, and training. The eight indicators are then broken down into 99 disclosure items. To measure and calculate the ICSR disclosure index, the Haniffa \& Hudaib (2007) method is used. Testing each disclosure indicator and the use of the variable form that represents the FP is the novelty of this study.

This research is expected to contribute to the development of knowledge of the results of the effect of ICSR disclosure with AAOIFI's standard No. 7 and other disclosure standards that have been widely used in annual reporting by overseas IBs on FP, which is expected to have implications for creating awareness of the use of these standards at IBs in Indonesia. The use of standardized disclosures provides benefits for stakeholders to be able to compare social performance among IBs. The standards used are issued by AAOIFI, because AAOIFI is an organization that formulates standards and issues related to accounting, auditing, governance, ethics, and Islamic sharia standards for Islamic Financial Institutions (IFI) in which are IBs, where Indonesia as a member of the organization has ratified the sharia standards published by AAOIFI. Previous research related to ICSR disclosure which refers to the standard of AAOIFI is Haniffa and Hudaib (2007), Maali et al. (2006), and Othman et al. (2009). Another contribution of this research is to strengthen the construction of stakeholder theory development in an Islamic perspective, which is currently being widely studied to strengthen the position of the theory in academia.

\section{Literature Review}

\section{Stakeholder Theory}

Stakeholders are all parties, both internal and external, who can influence or be influenced by the company either directly or indirectly (Freeman, 2010). Stakeholder theory initially emerged because of the growing awareness and understanding that the company has stakeholders, namely parties with an interest in the company. The idea that companies have stakeholders has been a topic of discussion in the management literature both academically and professionally.

Stakeholder theory is a theory which states that all stakeholders have the right to obtain information about company activities that can influence their decision making. Carroll and Buchholtz (2008) state that stakeholder theory can be seen in three approaches, namely descriptive, instrumental, and normative. The descriptive approach is a realistic picture of how the company operates. Descriptive approach aims to understand how managers handle stakeholder interests while still carrying out company interests. The instrumental approach states that one of the company's strategies is to produce good company performance by paying attention to stakeholders. The normative approach states that every person or group that contributes to the company's values has the moral right to receive an award, this is the management's obligation to fulfill the rights of stakeholders.

Stakeholder theory is a leading theory that is widely used by researchers to explain why companies should carry out social responsibility activities. Stakeholder theory emphasizes that there is a relationship between business and society; therefore, in carrying out its activities the company is morally responsible to stakeholders. Stakeholder theory states that in carrying out their operational activities, companies are not only looking for benefits for themselves, but they must also provide benefits for all stakeholders. Disclosure of information in company reports must pay attention to stakeholder expectations (Muslichah, 2020). 


\section{Stakeholders Theory in Islamic Perspective}

The Islamic perspective on social responsibility is that the activities carried out must help individuals or communities to improve their living conditions or their environment or help them to better comply with religious rules and norms (AAOIFI, 2010). Islam provides clear guidance to its followers in all aspects of life, based on the Al-Qur'an and alHadith, this is a responsibility in business, and is more valuable than just for financial gain alone, and is obligatory (Harun, 2016). in the Al-Qur'an to ensure social and economic justice between them.

There have been a lot of discussions about company behavior and its responsibility towards society (Sayyid et al., 1992). They explain that worldly goods are for the common good and that no one has the right to use them to harm other members of society. Islam teaches people how to develop morals, and use them for the development of their lives (Azid et al., 2007). Islam has laws relating to the corporate economy, which are different from conventional systems. Islamic norms are expected to change policies and business direction, where there is respect for investors, business initiators and the role of entrepreneurs in poverty alleviation, as well as the creation of companies that care about society in accordance with the Qur'an and Sunnah. In other words, Islam calls for socially responsible business (Azid et al., 2007).

Islam views that entrepreneurs are entitled to personal property and economic resources, gain profits, expand employment, increase investment, and increase welfare. However, it should be noted that the concept of ownership is not absolute, because man is the caliph, his duty is to use it according to Allah's guidance. In other words, the concept and function of property are changed by the provisions of moral and legal filters, so that property rights are subject to moral constraints and are used as a means to fulfill Islamic goals (Ahmed et al., 2012).

\section{Good Management Theory}

Good management theory, taken by Waddock and Graves (1997)in explaining the relationship between social responsibility disclosure and FP, is a further articulation of stakeholder theory (Donaldson \& Preston, 1995). The proposition developed under sound management theory is that a company should try to satisfy its stakeholders without presupposing its financial condition. Thus, the company will have a good image and reputation. Based on a resource-based perspective, attributes are one of the company's assets in an intangible component which is one of the components that contribute to the company's competitive advantage (Barney, 1991).

Basically, this theory encourages managers of a company to continue to look for better ways to increase the company's competitive advantage, which in turn can improve the company's FP (Asutay, 2013). According to Miles and Covin (2000), social and environmental activities are alternative ways to satisfy stakeholders and can be advantages that increase competitiveness. Proponents of good management theory also argue that good management practices have good relationships with stakeholders, and this in turn will improve the company's FP and competitive advantage (Donaldson \& Preston, 1995; Freeman, 2004; Waddock \& Graves, 1997).

\section{Corporate Social Responsibility in Islam}

The concept of social responsibility in Islam or ICSR has a broader and more basic meaning, which includes the dimensions of taqwa (God consciousness). The rule of law, morality, and justice are the cornerstones of the concept of ICSR (Khurshid et al., 2014). The ICSR paradigm in the view of Islam can be interpreted as a manifestation of human obedience to God, both individually and collectively, by "being kind" to all parties concerned. Companies as a group of individuals must take roles and responsibilities to contribute to social welfare. Thus, ICSR is a moral and religious initiative based on belief in God, as Owners of themselves and the resources they use in a company (Dusuki \& Abdullah, 2007). The goals of the Islamic social system are based on falah (human welfare) and hayat tayyibah (good life). These two goals are the basis of human behavior in social life and also for companies that bear social responsibility to support the achievement of these goals in a social order.

ICSR is not only horizontal (community and environmental) but also vertical, it must be accountable to Allah SWT (Iqbal \& Mirakhor, 2004). This is in accordance with the word of Allah SWT in the Qur'an Surah alBaqarah (2): 177. The verse explains that Islam is a religion that prioritizes the importance of social values in society. The Qur'an integrates the meaning and purpose of prayer with social values, apart from giving the value of faith to Allah SWT, the Qur'an states that faith is imperfect if it is not accompanied by social practices.

In the Islamic context, individual social responsibility comes from the words of Allah SWT and Rasulullah, as well as the main objective of doing business in accordance with sharia (Maali et al., 2006). Business is part of worship, and it is lawful for business to generate profits, but it must comply with sharia. In sharia, norms of human behavior have been regulated, and how business must be carried out by paying attention to the external environment, then business that is run according to sharia will have a clearer role in society. Islam requires the distribution of wealth to occur to all members of society and prevents the circulation of wealth to only a few people (Zia \& Nasiruddin, 2016). 
Discussions of social responsibility are frequently mentioned in the Qur'an and Hadith. The Qur'an is a guideline for business success and economic growth which is influenced by the entrepreneurial spirit of doing business (Yusuf, 2017). This shows that the concept of social responsibility and environmental preservation has long existed in Islam, according to the guidelines of the Prophet Muhammad. He carries out social responsibility and environmental preservation based on Al-Qu'ran guidelines (Yusuf, 2017).

\section{ICSR disclosure standard by AAOIFI}

AAOIFI published Standard No.7 In 2010 on the Governance Standard for Islamic Financial Institutions (GISFI) which contains corporate social responsibility conduct and disclosure for IFI (including IBs). The principles of this standard are applicable to all IFIs, regardless of their legal form, country of incorporation or size. However, the specific rules and provisions of this standard for activities, compliance and disclosure are classified into mandatory and recommended sections. The mandatory sections are applicable to all IFIs regardless of their legal form, country of incorporation or size. The recommended sections are only applicable to IFIs which have the capacity, financial or otherwise, to carry out or comply with such activities. Should the requirements of this standard contradict the IFI's charter or the laws and regulations of the country in which it operates, a disclosure should be made to that effect.

The primary objective of this GSIFI is to prescribe uniform standards on social responsibility activities and compliance for IFIs. It is not the intended objective of the standard to prescribe new principles and rules of conduct for IFIs, but to codify existing principles and rules in a comprehensive structured format. The second objective of this standard is to ensure that the social responsibility activities and compliance of IFIs are communicated in a uniform, truthful, transparent and comprehensible manner to relevant stakeholders to whom the IFI owes a duty of accountability. The objective of this standard, as stipulated above and the standard it self is intended to encourage IFIs to take a proactive role in applying social responsibility to all aspects of their operations (AAOIFI, 2010).

AAOIFI (2010) explained that the responsibilities under this standard are divided between mandatory and recommended conduct. Within mandatory conduct, there are specific responsibilities which an IFI must carry out, while there is guidance on the discretionary methods by which these specific responsibilities may be carried out. The mandatory conduct contents are policy for screening clients, policy for responsible dealing with clients, policy for earnings and expenditure prohibited by Sharia, policy for employee welfare, and policy for Zakah. The recommended conduct contents are policy for Qard Hasan, policy for reduction of adverse impact on the environment, policy for social, development and environment based investment quotas, policy for par excellence customer service, policy for micro and small business and social savings and investments, policy for charitable activities, and policy for Waqfmanagement.

Disclosure should be made, in a separate social responsibility report contained within the annual report, of the material policies of the IFI with respect to its mandatory social responsibility conduct to satisfy the information needs of the IFI's stakeholders. Disclosure may also be made in other reports specifically targeted towards the general public. It should be noted that while disclosures are meant to be comprehensive, the potential user groups of social responsibility information are wide, and hence disclosures should be designed with the intention of making them as understandable as possible for the general public (AAOIFI, 2010).

\section{Previous research in the ICSR}

A number of studies have examined the level of ICSR disclosure by Islamic banks using disclosure indexing techniques (Farook et al., 2011; Roszaini Haniffa \& Hudaib, 2007; Hassan \& Harahap, 2010; Maali et al., 2006; Mallin et al., 2014; Othman et al., 2009). Maali et al. (2006) investigated the extent to which the social activities expressed by 29 Islamic banks in the Gulf Cooperation Council (GCC) countries, by comparing the social disclosures carried out by Islamic banks with those of the public. The social practices expected by the community are then used as benchmarks for social reporting of Islamic banks and compared with annual reports with content analysis techniques. They find that the social disclosure practices of Islamic banks are far below the benchmark for disclosure based on the principles of sharia that should be.

Haniffa and Hudaib (2001) examined ethical identity based on Islamic values in 7 Islamic banks in GCC countries in the bank's annual report. They design ideal ethical disclosure standards based on five features that distinguish conventional Islamic banks by using content analysis in annual reports to determine the extent of ICSR disclosures. The results show a significant gap and conclude that in order for Islamic banks to remain competitive they must communicate more effectively to improve their image and reputation in society. The level of ICSR disclosure by Bank Islam Malaysia Berhad (BIMB) using a longitudinal case research approach, during the period 1992 to 2005. The results of his research show that the highest score is the disclosure of SSB. BIMB does not provide information in any form relating to the themes of restrictive supervision, illegal transactions, and the environment. Overall, the volume and quality of ICSR disclosures increased over the 14 year study period. Hassan and Harahap (2010) conducted a study focused on disclosure of social activities in the annual reports of seven 
Islamic banks in Indonesia. They find that the issue of social responsibility is not the main concern of most Islamic banks when viewed from the low index of social disclosure of large Islamic banks in Indonesia.

Farook et al. (2011) provide a basis for ICSR disclosure in Islamic banks, and investigate the extent of social responsibility disclosure in the annual reports of 47 Islamic banks in 14 countries. This study empirically analyses the level of disclosure based on the ICSR benchmark derived from the disclosure index of Maali et al. (2006). This study found significant differences in ICSR disclosure among these Islamic banks, and concluded that Islamic banks must establish SSB. Aribi and Gao (2012) analysed ICSR narrative disclosure in 21 IFIs operating in GCC countries to examine the influence of Islam on and disclosure of ICSR. They found that the disclosure of ICSR in the SSB report is very small when compared to the information on zakat, interest-free loans, and donations made in the bank's annual report. Effect of SSB and its characteristics on the level of ICSR disclosure in 53 Islamic banks operating in the GCC in 2008, with a disclosure index developed from an Islamic perspective. The results show that there is an increase in the ICSR information disclosed in the annual report. In addition, using multiple regression analysis it is found that SSB characteristics have a significant positive effect on ICSR disclosure. This shows that the characteristics of SSB are important factors in determining the level of ICSR disclosure.

Platonova et al. (2018) examined the relationship between social responsibility and financial performance for Islamic banks in GCC countries during the 2000-2014 period with data related to social responsibility through an analysis of annual disclosure reports. The findings of this study indicate that there is a significant positive relationship between ICSR disclosure and Islamic bank financial performance in GCC countries. Mallin et al. (2014) examined the relationship between ICSR disclosure and Islamic bank financial performance. This study uses the ICSR disclosure index which includes ten dimensions in 90 Islamic banks in 13 countries. The disclosure index shows that these Islamic banks are involved in various social activities. The results of this study indicate that the order of the disclosure index scores on commitment to vision and mission, board of commissioners and top management, and the dimensions of financial products/services, while very little attention is paid to the environmental dimension.

\section{ICSR disclosure and IBs performance}

A number of studies have been conducted to investigate the impact of social activities as measured by a disclosure index that shows social performance and its relationship to FP. The results of these studies are inconsistent due to differences in theoretical and methodological foundations (Griffin \& Mahon, 1997; Preston \& O'Bannon, 1997; Waddock \& Graves, 1997). However, there is no previous research that empirically examines the CSR-FP relationship specifically in the Islamic banking industry (Ahmed et al., 2012; Simpson \& Kohers, 2002; Soana, 2009).

Neoclassical economists are proponents of the negative relationship between social activities and FP (Simpson \& Kohers, 2002). They argue that companies that carry out social and environmental activities for the benefit of stakeholders will experience losses resulting in reduced profits due to the social costs incurred. Actually these costs can be avoided or borne by others (for example, the government). It can be argued from the perspective of an Islamic bank that helping to develop large-scale environmental and community projects can have a negative impact on the benefits (Mallin et al., 2014).

Stakeholder theory assumes that there is a positive relationship between social responsibility and FP. Waddock and Graves (1997) argue that the benefits of social responsibility outweigh the costs. Therefore, there is a positive association between social responsibility and FP. Preston and O'Bannon (1997) argue that meeting the needs of various corporate stakeholders improves a company's reputation and will have a positive impact on its FP. Simpson and Kohers (2002) empirical findings, based on data from a sample of US commercial banks, support the idea of a positive relationship between social responsibility and FP.

The social and environmental roles played by IBs in society will enhance their reputation which leads to a higher FP. Finally, the empirical findings of a neutral (non-existent) relationship between social and FP may be due to the complex relationship between society and company that cannot be captured through a simple direct relationship (Mallin et al., 2014). The implementation of social and environmental responsibility is not only about fulfilling legal and moral obligations, but also a strategy so that companies and communities continue to survive in the long term (Syukron, 2015). If social and environmental responsibility is not implemented, there will be more costs that must be borne by the company. Conversely, if the company carries out social and environmental responsibility properly and actively works hard to balance the rights of all stakeholders based on fairness, dignity, justice, and ensures a fair distribution of wealth, it will be beneficial for the company in the long term (Anto \& Astuti, 2012). In its social role, IBs are expected to provide economic and social benefits for their stakeholders, as well as to fulfil social responsibility including transparency (Mallin et al., 2014). Farook and Lanis (2005) argue that disclosure provides evidence of the involvement of IBs in social activities and thus obtains legitimacy for their existence. 
The hypothesis in this study was developed with the stakeholder theory as a grounded theory, which then along with the development of Islamic financial institutions a stakeholder theory construction in the Islamic perspective was formed. Hypothesis development is also supported by good management theory and literature review. The entire theoretical basis used states that there is a positive relationship between social and environmental activities on the FP of IBs. To obtain more detailed research findings, tests will be carried out for each indicator of ICSR disclosure on the performance of IBs.

The indicators and ICSR disclosure items were developed by researchers with reference to AAOIFI standards and previous researchers who were widely referred to in the preparation of disclosure items for IBs at home and abroad. The indicators are: sharia compliance, ethical behavior, management, human resources, environmental, social activities, products and services; and research, development and training. Thus the research hypothesis is:

$\mathrm{H}_{1}$ : sharia compliance disclosure has a positive effect on the performance of IBs

$\mathrm{H}_{2}$ : ethical behavior disclosure has a positive effect on the performance of IBs

$\mathrm{H}_{3}$ : management disclosure has a positive effect on the performance of IBs

$\mathrm{H}_{4}$ : human resources disclosure has a positive effect on the performance of IBs

$\mathrm{H}_{5}$ : environmental disclosure has a positive effect on the performance of IBs

$\mathrm{H}_{6}$ : social activities disclosure has a positive effect on the performance of IBs

$\mathrm{H}_{7}$ : product and service disclosure has a positive effect on the performance of IBs

$\mathrm{H}_{8}$ : research, development, and training disclosure has a positive effect on the performance of IBs

\section{Research Method}

\section{Population and Sample}

The population of this research is IBs in Indonesia, consisting of Islamic commercial banks and Islamic public finance banks. According to the 2020 Islamic Banking Statistics, the number of Islamic commercial banks is 12, and the Islamic people's finance bank is 165, thus the population of this study is 177 .

The sampling technique used was non probability sampling method, namely convenience sampling (Sekaran \& Bougie, 2016). Of the existing population, only Islamic commercial banks that provide complete and easy to obtain information, so that the samples of this research are 12 Islamic commercial banks. Observations for 12 years until 2019 (or from 2008 until 2019) are to strengthen the generalizability of research results. Islamic commercial banks that are not 12 years old or in 2008 not yet established, the observations are from its establishment until 2019. The observation results can be obtained by 121 observations (unbalance). Table 1 shows the names of the Islamic commercial banks samples and the years of observations.

Table 1 Number of Samples and Observations

\begin{tabular}{llcc}
\hline No. & \multicolumn{1}{c}{ Name of Sample } & Observation Year & $\begin{array}{c}\text { Number of } \\
\text { Observations }\end{array}$ \\
\hline 1. & Bank Muamalat Indonesia (BMI) & $2008-2019$ & 12 \\
2. & Bank Syariah Mandiri (BSM) & $2008-2019$ & 12 \\
3. & Bank Bukopin Syariah & $2008-2019$ & 12 \\
4. & Bank Mega Syariah & $2008-2109$ & 12 \\
5. & Bank Rakyat Indonesia (BRI) Syariah & $2009-2019$ & 11 \\
6. & Bank Negara Indonesia (BNI) Syariah & $2010-2019$ & 10 \\
7. & Bank Central Asia (BCA) Syariah & $2010-2019$ & 10 \\
8. & Bank Panin Syariah & $2010-2019$ & 10 \\
9. & Bank Victoria Syariah & $2011-2019$ & 9 \\
10. & Maybank Syariah & $2011-2019$ & 9 \\
11. & Bank Jabar dan Banten (BJB) Syariah & $2012-2019$ & 8 \\
12 & Bank BTPN Syariah & $2014-2019$ & 6 \\
& & Number of observations & 121 \\
\hline
\end{tabular}

\section{Definitions of Variables}

\section{Dependent variable and its measurement}

The dependent variable used is the performance of ROA, ROE, and Productivity. The three variables are then formed into variable formation by factor analysis.

The operational definition and measurement of the dependent variables are:

1) Return on Asset (ROA) is profit after tax divided by total assets. This ratio shows the bank's ability to generate profits from the use of assets. 
2) Return on Equity (ROE) is profit after tax divided by total equity. This ratio shows how the bank can generate return on money invested by shareholders.

3) Productivity is total operating income divided by total assets. This ratio measures the company's ability to generate income with its assets.

\section{Independent variable and its measurement}

The independent variable is the level of ICSR disclosure. The operationalization of the ICSR disclosure variable is by developing disclosure indicators and items. These indicators and disclosure items use disclosure indicators and items from AAOIFI Standard No. 7 and previous research (Haniffa \& Hudaib, 2007; Hassan \& Harahap, 2010; Maali et al., 2006; Othman \& Thani, 2010; Yusuf, 2017), consisting of 8 indicators and 74 disclosure items.

Measurement of the ICSR disclosure variable uses a dichotomous scoring with a score of 1 if disclosed, and 0 if not disclosed. Then from the scores that have been made, a disclosure index is made, as done by Haniffa and Cooke (2005), Roszaini Haniffa and Hudaib (2007), Hassan and Harahap (2010). The formula is as follows:

ICSR Disclosure Index $\left(\mathrm{DI}^{-\mathrm{ICSR}_{j}}\right)=\frac{\sum_{i}^{n}=X_{i j t}}{N}$

Where:

DI-ICSR $_{\mathrm{jt}}:$ ICSR disclosure index for dimension $j$ and indicator $t$

$X_{i j t} \quad:$ variable $\mathrm{X}$ from 1 to $n$ for dimension $j$ and period $t, 1$ if disclosed and 0 if not

$N \quad$ : number of variables/statement and $\mathrm{X}_{i j}=1$ if $i$ th item is not disclosed, that $0, \mathrm{I}_{j}<1$.

The data of this study will be processed by using panel regression model, after fulfilling all the classical assumption tests (normality, multicollinearity, and heteroscedasticity). For panel data there is no need for an autocorrelation test. The panel regression model is used to find out the most efficient model from the three equation models, namely the Common Effect Model (CEM), Fixed Effect model (FEM) and Random Effect Model (REM) by using e-views software. The regression equation is as follow:

$\mathrm{IBP}_{\mathrm{it}}=\beta_{0}+\beta_{1}(\mathrm{SC})_{1 \mathrm{it}}+\beta_{2}(\mathrm{EM})_{2 \mathrm{it}}+\beta_{3}(\mathrm{M})_{3 \mathrm{it}}+\beta_{4}(\mathrm{HR})_{4 \mathrm{it}}+\beta_{5}(\mathrm{E})_{5 \mathrm{it}}+\beta_{6}(\mathrm{SA})_{6 \mathrm{it}}+\beta_{7}(\mathrm{PS})_{7 \mathrm{it}}+\beta_{8}(\mathrm{RDT})_{8 \mathrm{it}}++\mathrm{e}_{\mathrm{it}}$

Where:

IBP : Islamic Bank Performance

SC : Sharia Compliance

EM : Ethical Behavior

M : Management

HR : Human Resources

E : Environment

SA : Social Activity

PS : Products and Services

RDT : Research, Development, \& Training

\section{Results and Discussion}

Table 2 shows the results of descriptive analysis to provide an explanation that makes it easier to interpret the results of data analysis and discussion.

Table 2 Descriptive Statistics

\begin{tabular}{|c|c|c|c|c|c|c|}
\hline & $\mathrm{N}$ & Range & Minimum & Maximum & Mean & Std. Deviation \\
\hline ROA & 121 & 33.73 & -20.13 & 13.60 & .9345 & 3.73289 \\
\hline ROE & 121 & 151.99 & -94.01 & 57.98 & 6.5972 & 15.66360 \\
\hline Productivity & 121 & .45505 & .04695 & .50201 & .16690 & .09941 \\
\hline SC & 121 & .36363 & .63636 & 1.00000 & .84372 & .08721 \\
\hline EM & 121 & .44444 & .55555 & 1.00000 & .93663 & .087048 \\
\hline M & 121 & .55555 & .55555 & 1.11111 & .96437 & .073261 \\
\hline HR & 121 & .61538 & .38461 & 1.00000 & .89574 & .14891 \\
\hline E & 121 & 1.00000 & .00000 & 1.00000 & .30991 & .32653 \\
\hline SA & 121 & 1.00000 & .00000 & 1.00000 & .82879 & 19027 \\
\hline PS & 121 & .55555 & .44444 & 1.00000 & .81577 & 11978 \\
\hline RDT & 121 & .60 & .40 & 1.00 & .5793 & 20069 \\
\hline Valid N (listwise) & 121 & & & & & \\
\hline
\end{tabular}


The FP of ROA and ROE of IBs in Indonesia in the decades 2008-2019 where the highest performance occurred in 2017 for BTPN Syariah for ROA and in 2012 vary widely, for Bank Mega Syariah for ROE, on the other hand the peak of the worst FP in that decade occurred in 2015 for Maybank Syariah for ROA and in 2017 for Bank Panin Syariah. Due to these extreme conditions, the standard deviation of FP is above the average FP, with a very large range of performance. This can also be seen in other performance, namely productivity. This ratio measures the company's ability to generate income with its assets, a high value indicates high productivity at the bank concerned in utilizing its assets. The highest value occurred in 2011 by BCA Syariah, on the contrary, the lowest occurred in 2008 at Bank Bukopin Syariah. This small range is also seen in the standard deviation value at a position below the average productivity performance. The results of the descriptive analysis above show that in the decade ending 2017 there was a fairly high-performance achievement gap, where the highest performance achievement was achieved by BNI Syariah in 2011 and the lowest at BMI in 2015 and 2017, however, this large performance achievement gap did not reach at a position where the standard deviation is above the mean.

The average disclosure index for each indicator of ICSR disclosure is quite high, which is above $80 \%$, except for environmental indicators and research, development and training. This is to become a concern for IBs in the following periods to increase awareness of the environment and for the sustainability of IBs, they must pay attention to research, development and training. The highest disclosure index on management indicators shows the high integrity of the IBs in an effort to transparency of information to maintain stakeholder trust.

The low standard deviation and range $(<1)$ for all ICSR disclosure indices illustrates that all IBs in Indonesia have a good understanding of the principles of transparency and accountability to stakeholders. Special attention needs to be paid to the index of environmental disclosure and social activities, on the one hand the index of disclosure reaches the highest value of 1 , but on the other hand the index has the lowest value of 0.00000 . This illustrates the still far gap between social and environmental activities among IBs in Indonesia.

\section{Regression Test Result}

The results of regression testing, all variables are significant. The coefficient of determinant for testing this regression model is 0.631 . This means that the independent variables can explain the dependent variable of bank performance by $63 \%$. All significant variables have a positive coefficient, thus all hypothesis are statistically accepted.

Table 3. Regression Test Result

\begin{tabular}{|c|c|c|c|c|c|}
\hline Variable & Coefficient & Std. Error & t-Statistic & Sign & Conclusion \\
\hline SC & .606 & .447 & 1.355 & $.017^{*}$ & Accepted \\
\hline EM & .941 & .472 & 1.995 & $.048 *$ & Accepted \\
\hline M & .002 & .580 & .003 & $.029 *$ & Accepted \\
\hline HR & .194 & .308 & .631 & $.025^{*}$ & Accepted \\
\hline$E$ & .240 & .153 & 1.572 & $.011 *$ & Accepted \\
\hline SA & .474 & .249 & 1.904 & $.039 *$ & Accepted \\
\hline PS & .151 & .323 & .468 & $.046 *$ & Accepted \\
\hline RDT & .449 & .195 & 2.304 & $.023 *$ & Accepted \\
\hline $\mathrm{F}$ & 68.143 & & & .000 & \\
\hline Adjusted $\mathrm{R}^{2}$ & 0.631 & & & & \\
\hline R-Squared & 0.646 & & & & \\
\hline
\end{tabular}

Significant 5\%

\section{Discussion}

Empirical analysis shows a positive relationship between the ICSR disclosure index and the performance of IBs, this result supports the results of previous studies (Mallin et al., 2014). The positive effect of ICSR disclosure on bank performance illustrates that social and environmental activities provide a positive image and reputation for the community, which creates trust and in the long term bank performance will increase, this supports the research of Barney (1991). The positive effect of corporate social performance on future FP is due to the positive impact of CSR disclosure on bank reputation. As a result, banks that are more socially active can increase customer loyalty and get support from a wider range of stakeholders, which in turn can make a positive contribution to FP Platonova et al. (2018). The positive effect of ICSR disclosure on bank performance also supports the research of Preston and O'Bannon (1997) and Waddock and Graves (1997) which concluded that the potential benefits of social and environmental activities exceed the costs incurred for these activities.

The results of this study are consistent with stakeholder theory and good management theory. In stakeholder theory there are three approaches, one of which is the normative approach which says that every person or group that contributes to the company's values has the moral right to receive an award, this is the management's obligation to fulfil the rights of stakeholders. Another approach is instrumental, which states that one of the 
company's strategies is to produce good company performance by paying attention to stakeholders, so that social and environmental activities reflected in voluntary disclosure are IBs' long-term strategy to maintain its performance. Related to the theory of good management, social and environmental activities are carried out by IBs to satisfy its stakeholders without presuming its financial condition. Thus the IBs will have a good image and reputation. Attribute is one of the company's assets in an intangible component that contributes to the company's competitive advantage which is characterized by good performance. Basically, this theory encourages managers of a company to continue to look for better ways to increase the company's competitive advantage, which in turn can improve the company's FP (Asutay, 2013).

From an Islamic perspective it is an internal consequence of Islamic teachings themselves. The purpose of Islamic law is maslahah so that business is an effort to create maslahah, not just for profit. Business in Islam is not only permissible, but is commanded by Allah in the Qur'an Surah (QS) al-Jumu'ah (62) 10: "When prayers have been fulfilled, then you will be scattered on the face of the earth; and seek Allah's grace and remember. Allah is abundant so that you will be lucky. "The commandment of Allah SWT to do good to the social environment is in QS al-Baqarah (2) 148:" And for each ummah there is its (own) qibla which he faces Him. So compete in goodness. Wherever you are, Allah will gather you all (on the Day of Resurrection). Verily Allah has power over all things ".

In the Islamic concept, it provides an explanation of the influence related to human responsibility to Allah SWT as the main stakeholder, this is the core of stakeholder theory in an Islamic perspective. The form of the relationship that underlies the existence of this influence arises from the basic concept of mandate in the framework of a single absolute of divine power (Yuwono, 1997). The absolute value that appears in the interaction between safeguards (Allah SWT) and those given the mandate (humans) is solely due to divine power. In other words, the essence that occurs in the management of IBs is a mandate for an ownership entrusted by Allah to them as a manifestation of human function as Khalifatullah Fill Ardh. In relation to human existence as mentioned above, the main purpose of human existence as a mandate bearer is to spread rachmatan lil alamin, there is no reason to direct this goal into the power of lust for mere gain (Yuwono, 1997).

\section{Conclusions}

The conclusion from the results of this study is that all indicators of ICSR disclosure have an effect on the performance of IBs. But it needs to be paid attention to environmental indicators and social activities that have the lowest average disclosure index compared to other disclosure indices. This means that IBs' concern for the environment and social activities is still low, although the disclosure of the 2 indicators also has a positive effect on its performance. Other results show that the involvement of IBs in CSR as indicated by the high index of disclosure on indicators of sharia compliance, risk management, and management is quite large. This reflects the professionalism of IBs management in Indonesia, because these three indicators illustrate the extent to which IBs managers have a good understanding of Islamic laws and banking financial issues, and also reflect the IBs manager's compliance with all regulations, especially those related to risk management regulations.

This finding has a number of policy implications. First, the implications are related to the low awareness of the environment and social activities, so there needs to be an affirmation from the IBs management to pay more attention to the environment and social activities considering this is very beneficial in the long term in the form of improved performance. Second, regulators in the future can be more active in encouraging IBs to adopt AAOIFI Standard No.7 as a benchmark, because this will create a uniform ICSR disclosure that is useful for stakeholders to be able to compare the social performance of Islamic banking in Indonesia. Such policies may include the need for professional training programs including increased understanding that good IBs performance can also be achieved through social and environmental activities.

This study has several limitations and it is hoped that it can be improved in future studies. The limitations of this study are: first, this study uses the ICSR disclosure, but the researcher does not discuss the quality of disclosure. Second, this study does not test the reliability of the ICSR disclosure. The author provides suggestions for further research to consider the quality of disclosure, namely: completeness, accuracy, and reliability to produce better research findings. The next suggestion for further research is that it is necessary to test the reliability of the ICSR disclosure.

\section{References}

AAOIFI. (2010). Corporate Social Responsibility Conduct and Disclosure for Islamic Financial Institutions (Governance Standard No.7).

Ahmed, S. U., Islam, M. Z., \& Hasan, I. (2012). Corporate social responsibility and financial performance linkageevidence from the banking sector of Bangladesh. Journal of Organizational Management, 1(1), 14-21.

Anto, M. H., \& Astuti, D. R. (2012). Persepsi stakeholders terhadap pelaksanaan corporate sosial responsibility: Kasus pada bank Syariah di DIY. Sinergi: Kajian Bisnis Dan Manajemen, 101), 19-30. 
Aribi, Z. A., \& Gao, S. (2011). Narrative disclosure of corporate social responsibility in Islamic financial institutions. Managerial Auditing Jounal, 27(2), 199-222. https://doi.org/10.1108/02686901211189862

Aribi, Z. A., \& Gao, S. S. (2012). Narrative disclosure of corporate social responsibility in Islamic financial institutions. Managerial Auditing Journal, 27(2), 199-222.

Arshad, R., Othman, S., \& R. Othman. (2012). Islamic corporate social responsibility, corporate reputation and performance. World Academy of Science, Engineering and Technology, International Journal of Social, Behavioral, Educational, Economic, Business and Industrial Engineering, 6, 643-647.

Asutay, M. (2013). Islamic moral economy as the foundation of Islamic finance. In V. Cattelan (Ed.), Islamic Finance in Europe Towards a Plural Financial System. Edward Elegar.

Azid, T., Asutay, M., \& Burki, U. (2007). The theory of firm, management and stakeholders: An Islamic scenario perspective. Islamic Economic Studies, 15(1), 1-30.

Barney, J. (1991). Firm resource and sustained competitive advantage. Journal of Management, 17(1), 99-120.

Bayoud, N. S., Kavanagh, M., \& Slaughter, G. (2012). Factors influencing levels of corporate social responsibility disclosure by Libyan firms: A mixed study. International Journal of Economics and Finance, 4(4), 13-29.

Carroll, A. B., \& Buchholtz, A. K. (2008). Business and Society: Ethics and Stakeholder Management (7th ed.). South-Western College.

Donaldson, T., \& Preston, L. E. (1995). The stakeholder theory of the corporation: Concepts, evidence, and implications. The Academy of Management Review, 20(1), 65-91.

Dusuki, A. W., \& Abdullah, N. I. (2007). Maqasid al-shari'ah, maslahah and corporate social responsibility. Journal of Islam and Society, 24(1), 25-45.

Farook, S., Hassan, M. K., \& Lanis, R. (2011). Determinant of corporate social responsibility disclosure: the case Of Islamic banks. Journal of Islamic Accounting and Business Research, 2(2), 114-141.

Farook, S., \& Lanis, R. (2005). Banking on Islam? Determinants of corporate social responsibility disclosure. 6th International Conference on Islamic Economic and Finance.

Freeman, R. E. (2004). The stakeholder approach revisited. Zeitschrift Für Wirtschafts- Und Unternehmensethik, $5(3), 228-254$.

Freeman, R. E. (2010). Strategic Management: A Stakeholder Approach. Cambridge University Press.

Griffin, J. J., \& Mahon, J. F. (1997). The corporate social performance and corporate financial performance debate: Twenty-Five years of incomparable research. Business \& Society, 36(1), 5-31.

Haniffa, R. M., \& Cooke, T. E. (2005). The impact of culture and governance on corporate social reporting. Journal of Accounting and Public Policy, 24(5), 391-430. https://doi.org/10.1016/j.jaccpubpol.2005.06.001

Haniffa, Ros. (2002). Social reporting disclosure-an Islamic perspective. Indonesian Management \& Accounting Research, 1(2), 126-146.

Haniffa, Roszaini, \& Hudaib, M. (2007). Exploring the ethical identity of Islamic banks via communication in annual reports. Journal of Business Ethics, 76(1), 97-116.

Haniffa, Roszaini Mohamad, \& Hudaib, M. A. (2001). A Theoretical Framework for the Development of the Islamic Perspective of Accounting. Accounting, Commerce \& Finance: The Islamic Perspective International Conference, 1-41.

Harun, M. S. Bin. (2016). The Impact Of Corporate Governance And Its Consequences On CSR Disclosure: Empirical Evidence From Islamic Banks in GCC Countries. Plymouth University.

Hassan, A., \& Harahap, S. S. (2010). Exploring corporate social responsibility disclosure: The case of Islamic banks. International Journal of Islamic and Middle Eastern Finance and Management, 3(3), 203-227.

Iqbal, Z., \& Mirakhor, A. (2004). Stakeholders model of governance in Islamic economic system. Islamic Economic Studies, 11(2), 43-63.

Khurshid, M. A., Al-Aali, A., Soliman, A. A., \& Amin, S. M. (2014). Developing an Islamic corporate social responsibility model (ICSR). Competitiveness Review, 24(4), 258-274.

Maali, B., Casson, P., \& Napier, C. (2006). Social reporting by Islamic banks. Abacus, 42(2), 266-289. 
Makni, R., Francoeur, C., \& Bellavance, F. (2009). Causality between corporate social performance and financial performance: Evidence from Canadian firms. Journal of Business Ethics, 89(409), 409-422.

Mallin, C., Farag, H., \& Ow-Yong, K. (2014). Corporate social responsibility and financial performance in Islamic banks. Journal of Economic Behavior \& Organization, 103, S21-S38.

Margolis, J. D., \& Walsh, J. P. (2003). Misery loves companies: Rethinking social initiatives by business. Administrative Science Quarterly, 48(2), 268-305.

Marom, I. Y. (2006). Toward a unified theory of the CSP-CFP link. Journal of Business Ethics, 67, 191-200.

Miles, M. P., \& Covin, J. G. (2000). Environmental marketing: a source of reputational, competitive and financial advantage. Journal of Business Ethics, 23, 299-311.

Muslichah. (2020). The effect of environmental , social disclosure, and financial performance on firm value. Jurnal Akuntansi \& Auditing Indonesia, 24(1), 22-32.

Othman, R., \& Thani, A. M. (2010). Islamic social reporting of listed companies in Malaysi. International Business \& Economics Research Journal, 9(4), 135-144.

Othman, R., Thani, A. M., \& Ghani, E. K. (2009). Determinants of Islamic social reporting among top shariahapproved companies in Bursa Malaysia. Research Journal of International Studies, 12, 4-20.

Platonova, E., Asuta, M., Dixon, R., \& Mohammad, S. (2018). The impact of corporate social responsibility disclosure on financial performance: Evidence from the GCC Islamic Banking Sector. Journal of Business Ethics, 151(2), 451-471.

Preston, L. E., \& O'Bannon, D. P. (1997). The corporate social financial performance relationship: A typology and analysis. Business and Society, 36(4), 419-529.

Republic of Indonesia. (2008). Law of the Republic of Indonesia number 21 year 2008 on Sharia Banking. Sekertariat Negara.

Sayyid, T., Agil, S. O. S., \& Ghazali, A. (1992). Readings in Microeconomics: An Islamic Perspective. Longman.

Sekaran, U., \& Bougie, R. (2016). Research Method for Business Textbook: A Skill Building Approach. Wiley.

Simpson, W. G., \& Kohers, T. (2002). The link between corporate social and financial performance: Evidence from the banking industry. Journal of Business Ethics, 35, 97-109.

Soana, M.-G. (2009). The relationship between corporate social performance and corporate financial performance in the banking sector. Journal of Business Ethics, 104(1), 133-148.

Syukron, A. (2015). CSR dalam perspektif Islam dan perbankan syariah. Economic: Jurnal Ekonomi Dan Hukum Islam, 5(1), 1-22.

Ullmann, A. A. (1985). Data in search of a theory: A critical examination of the relationship among social performance, social disclosure, \& economic performance. The Academy of Management Review, 10(3), $540-557$.

Waddock, S. A., \& Graves, S. B. (1997). The corporate social performance-financial performance link. Strategic Management Journal, 18(4), 03-319.

Yusuf, M. Y. (2017). Islamic Corporate Social Responsibility (I-CSR) Lembaga Keuangan Syariah (Teori dan Praktek). Kencana.

Yuwono, I. T. (1997). Akuntansi syari 'ah dan koperasi mencari bentuk dalam bingkai metafora amanah. Jurnal Akuntansi \& Auditing Indonesia, 1(1), 1-46.

Zia, M. D., \& Nasiruddin, N. (2016). Islamic economic rationalism and distribution of wealth: a comparative view. IOSR Journal of Business and Management, 18(4), 43-52. 